\title{
Culturable Yeasts as Biofertilizers and Biopesticides for a Sustainable Agriculture: A Comprehensive Review
}

\author{
María Hernández-Fernández $\left(\mathbb{D}\right.$, Gustavo Cordero-Bueso * ${ }^{\mathbb{D}}$, Marina Ruiz-Muñoz and Jesús M. Cantoral 1 \\ Laboratory of Microbiology, Department Biomedicine, Biotechnology and Public Health, University of Cádiz, \\ Puerto Real, 11510 Cádiz, Spain; maria.hernandez@uca.es (M.H.-F.); marina.ruiz@uca.es (M.R.-M.); \\ jesusmanuel.cantoral@uca.es (J.M.C.) \\ * Correspondence: gustavo.cordero@uca.es
}

check for updates

Citation: Hernández-Fernández, M.; Cordero-Bueso, G.; Ruiz-Muñoz, M.; Cantoral, J.M. Culturable Yeasts as Biofertilizers and Biopesticides for a Sustainable Agriculture: A Comprehensive Review. Plants 2021, 10, 822. https://doi.org/10.3390/ plants10050822

Academic Editor:

Chrystalla Antoniou

Received: 24 February 2021

Accepted: 19 April 2021

Published: 21 April 2021

Publisher's Note: MDPI stays neutral with regard to jurisdictional claims in published maps and institutional affiliations.

Copyright: (c) 2021 by the authors. Licensee MDPI, Basel, Switzerland. This article is an open access article distributed under the terms and conditions of the Creative Commons Attribution (CC BY) license (https:// creativecommons.org/licenses/by/ $4.0 /)$.
Abstract: The extensive use of synthetic fertilizers and pesticides has negative consequences in terms of soil microbial biodiversity and environmental contamination. Faced with this growing concern, a proposed alternative agricultural method is the use of microorganisms as biofertilizers. Many works have been focused on bacteria, but the limited literature on yeasts and their potential ability to safely promote plant growth is gaining particular attention in recent years. Thus, the objective of this review is to highlight the application of yeasts as biological agents in different sectors of sustainable agricultural practices through direct or indirect mechanisms of action. Direct mechanisms include the ability of yeasts to provide soluble nutrients to plants, produce organic acids and phytohormones (indole-3-acetic acid). Indirect mechanisms involve the ability for yeasts to act as biocontrol agents through their high antifungal activity and lower insecticidal and herbicidal activity, and as soil bioremediating agents. They also act as protective agents against extreme environmental factors by activating defense mechanisms. It is evident that all the aspects that yeasts offer could be useful in the creation of quality biofertilizers and biopesticides. Hence, extensive research on yeasts could be promising and potentially provide an environmentally friendly solution to the increased crop production that will be required with a growing population.

Keywords: yeasts; sustainability; biocontrol; growth promoters; bioinsecticides; antifungals; biostimulants

\section{Introduction}

Fertilizers are essential to foster the growth of high yield crops. Of the basic nutrients that plants need for healthy growth, large amounts of nitrogen (taken up as $\mathrm{NH}_{4}+$ or $\mathrm{NO}_{3}{ }^{-}$), phosphorus (taken up as $\mathrm{H}_{2} \mathrm{PO}_{4}{ }^{-}$), calcium (taken up as $\mathrm{Ca}^{2+}$ ), sulfur (taken up as $\mathrm{SO}_{4}{ }^{2-}$ ), magnesium (taken up as $\mathrm{Mg}^{2+}$ ), potassium (taken up as $\mathrm{K}^{+}$), iron (taken up as $\mathrm{Fe}^{2+}$ or $\mathrm{Fe}^{3+}$ ) and zinc (taken up as $\mathrm{Zn}^{2+}$ or $\mathrm{Zn}(\mathrm{OH})_{2}$ ) are required by many crops on most soils [1]. Such large amounts of nitrogen, phosphorus, sulfur and potassium nutrients are supplied mainly in the form of mineral fertilizers, either processed natural minerals or manufactured chemicals [2]. The development and use of mineral fertilizers after the Second World War have provided significant increases in crop yield using less land, which assisted in supporting the burgeoning population [3].

Since the 1960s, there are increasingly studies with alarming data on animal and human health related to the widespread use of mineral fertilizers [3-5]. Likewise, the uncontrolled use of fertilizers has reduced microbial activity and soil fauna, causing a significant loss of biodiversity, as well as an increase in groundwater pollution, mostly from nitrates [6]. According to Regulation (EU) 2019/1009 of the European Parliament and of the Council on 5 June 2019, the different maximum amounts of nitrate to be added according to the fertilizer to be used are specified, as well as the rest of the compounds that compose it. 
Over the next thirty years, the world population is expected to reach almost 10 billion. Thus, in order to meet the estimated food demand in 2050, food and feed supplies will need to increase by $60 \%$ [7]. To avoid potential supply shortages, food production and distribution must be managed in a more efficient and sustainable way. In order to achieve this, some producers are turning to organic fertilizers which come from many different recycled sources, including manure, crop residues, and town sewage such as human waste [8]. Organic fertilizers offer some benefits that have contributed greatly to maintaining crop yields; however, they are usually lower in nutrients and less effective in supporting plant growth when used together with chemical fertilizers. For instance, the total nutrients in manure are less than $2 \%$ and the levels of phosphorus and nitrogen nutrients therein are more difficult to be effectively utilized. This is due to their losses into the environment, thus contributing to soil contamination and the eutrophication of lakes, underground aquifers and coastal areas [8]. Moreover, unprocessed organic fertilizers also affect animal and human health since they may contain pathogenic microorganisms, such as the harmful bacteria species Escherichia coli, or the genera Campylobacter, Salmonella, Clostridium botulinum, among others [9]. Furthermore, organic fertilizers can produce undesirable odors [10] and may contain toxic chemicals that can pose a risk to human, animal or plant health [11]. These and other harmful side effects have led the European Union and other countries to restrict the use of such fertilizers (European Commission Regulation, 2008).

Biostimulants are natural substances or microorganisms that are applied to plants with the aim of improving their nutritional efficiency, tolerance to abiotic stress and/or quality traits of crops, regardless of their nutrient content. Biofertilizers, a subcategory of biostimulants, can be defined as microbial inoculants, in which active or inactive formulations of beneficial microorganisms can improve the nutritional efficiency of plants [12-14]. Bhardwaj et al. (2014) reported that the use of biofertilizers raised crop yields around 10-40\%, which increased the content of proteins, essential amino acids, vitamins, and nitrogen fixation [15]. Consequently, biofertilizers have been proposed as an alternative to mineral fertilizers. For example, nitrogen and/or sulfur fixing microorganisms including bacteria, such as Azotobacter, Azospirillum and Rhizobium, and fungi, such as Aspergillus niger and A. tubingensis have been utilized in biofertilizers [16-19]. Genetically modified bacterial strains have also been developed and tested as biological fertilizers [20]. The application of bacteria and fungi as biofertilizing agents has generated growing enthusiasm for being an eco-friendly alternative to synthetic fertilizers. However, their still low effectiveness in comparison to conventional fertilizers reduce their current application [21-23].

Similarly, increased crop production relies on disease and pest control management. In fact, pest management is the main aspect of obtaining high and healthy crop yields [24]. Approximately 50,000 species of fungi, 18,000 species of weeds and 10,000 species of insects have been described as damaging crops and food worldwide [25]. In order to control them, synthetic pesticides are the most widely used alternative. However, their inappropriate and extended use have led to resistance in these organisms. Furthermore, their non-biodegradability and toxicity have led to reconsideration of the use of sustainable pest control measures. In this regard, Annex II of Regulation (EC) 1107/2009 of the European Parliament and of the Council of 21 October 2009, concerning the commercialization of phytosanitary products, introduced so-called cut-off criteria, which directly prohibit the use of numerous substances, such as pesticides. Thus, the application of microbial pesticides appears as a promising alternative [26]. Biopesticides are products containing microorganisms that are widely used for pest control management in sustainable agriculture [27]. Nowadays, biopesticides are only used in 5\% of crops. Therefore, the research and introduction of new microbial agents that can protect plants is a fundamental strategy to cover new needs in this field [28]. In this regard, there is a current growing interest in the study of yeasts with potential to be used as biofertilizers or biopesticides.

Yeasts are single-cell fungi that can assimilate different carbon and nitrogen sources. Because they are facultatively anaerobic, some also have the ability to ferment carbo- 
hydrates. Its main mode of reproduction is asexual, by budding or cell fission. This characteristic allows them to adapt to growth both in liquid environments, whether in suspension or forming biofilms, as well as solids, including sand grains [29]. Due to their wide nutritional activity and their easy proliferation capacity, yeasts are relatively abundant in the edaphic ecosystem [30]. As a consequence of their adaptation to the habitat, they can assimilate a large number of toxic compounds from synthetic pesticides, thus contributing to soil bioremediation [31]. Considerable progress has been made in increasing research showing that plant growth can be enhanced by yeasts. Some of their positive effects could be due to the provision of soluble nutrients and the production of different phytohormones and enzymes that directly contribute to plant growth, acting as biostimulants [32-34].

Biological control is another mechanism in which antagonistic microorganisms can be useful. The modes of action usually involved include: (i) competition for nutrients and space; (ii) production of toxins; (iii) secreted enzymes; (iv) production of volatile organic compounds (VOCs); (v) parasitism; (vi) induced systemic resistance [12,35]. In this way, yeasts act as biocontrol agents through an antagonistic action against pathogenic microorganisms that indirectly affect plant growth, acting mainly as a biofungicide and, to a lesser extent, as a bioinsecticide or bioherbicide [36-41]. In response to extreme environmental factors such as salinity, high temperature, drought or metal toxicity affecting plants, several defense mechanisms are activated by yeasts, which lie in the production of compounds that reduce such stress [42,43]. Both the large variety of mechanisms used and the intrinsic characteristics they present make them a promising microorganism as an alternative in different fields of agriculture (Figure 1).

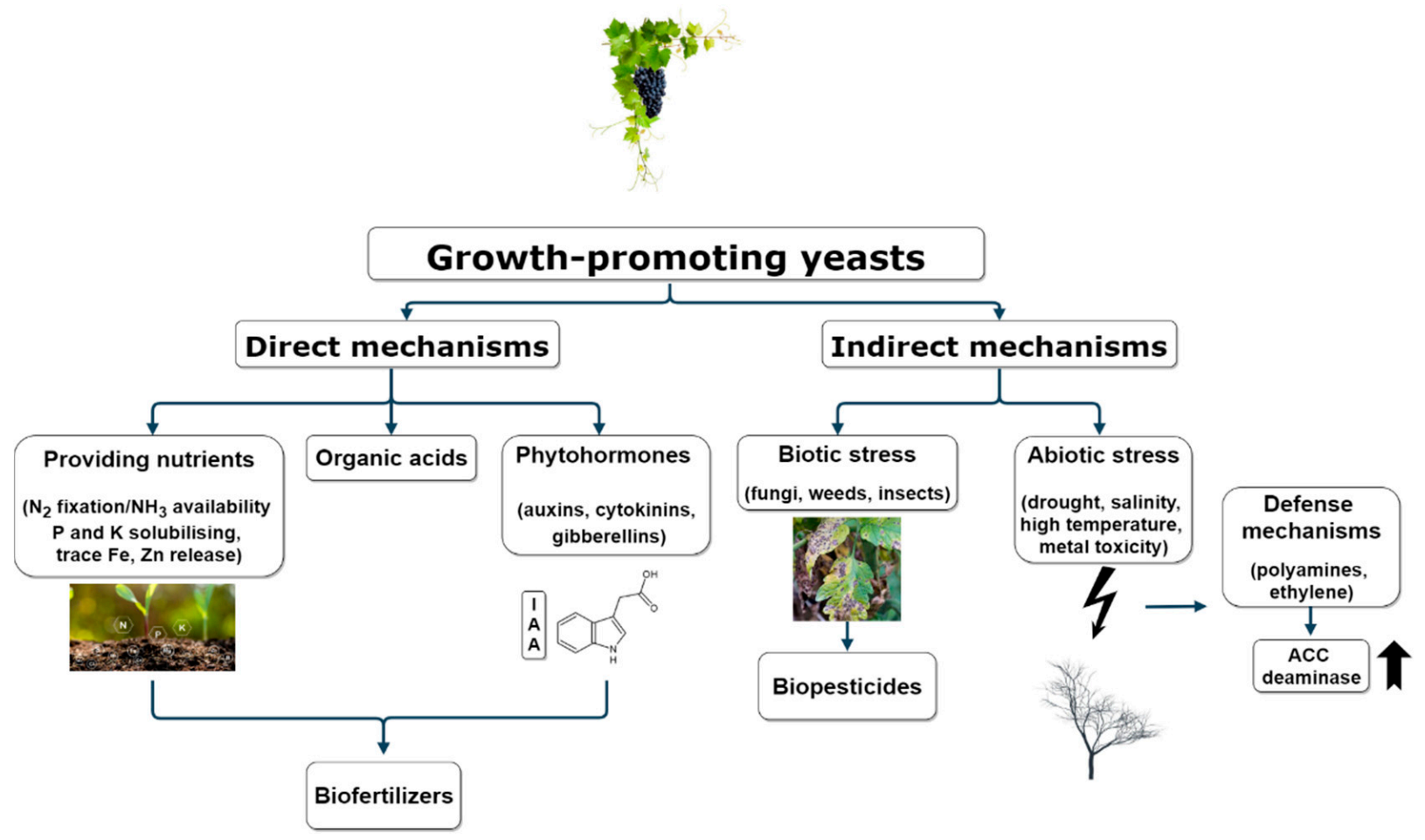

Figure 1. Modes of action of yeasts promoting plant growth.

This review collects information from various studies carried out with yeasts to promote sustainable agriculture, working both as biostimulant and biopesticide. It also aims to highlight the need to strengthen the study of yeasts and their mechanisms of action. A better understanding of these new avenues of research could constitute a valuable role in the environment that would reduce and potentially eliminate the need for synthetic fertilizers. 


\section{European and International Regulations on the Use of Biostimulants and Biopesticides}

Legislation on the use of biostimulants and biopesticides in different countries is not consistent, which has led to a biased variety and availability of fertilizers among farmers in different regions. To eliminate such biases, it is necessary to create a common marketplace for these substances. In addition, greater regulatory coherence accompanied by a better understanding of biostimulants and biopesticides would allow the reliability of their concept and could benefit the growth of their market [12,44].

\subsection{Biostimulant Regulations}

Microbial biostimulants are regulated at the national level, so the wide diversity of existing legislation has created some uncertainty among farmers [45]. However, the European Parliament has recently launched a new regulation, known as "Regulation European Union (EU) 2019/1009 laying down rules on the making available on the market of EU fertilizing products and amending Regulations European Commission (EC) 1609/2009 and EC 1107/2009", which aims to harmonize the EU biostimulant market. They indicated that microbial plant biostimulant will be constituted by the microorganism or group of microorganisms mentioned in the component materials category (CMC 7): Azotobacter spp., Rhizobium spp., Azospirillum spp. and mycorrhizal fungi. However, this regulation will not come into effect until July 2022.

On December 2018, the USA Agriculture Improvement Act of 2018 became law. Currently, definitive guidance is being generated by the Environmental Protection Agency (EPA) for the regulation of plants, including biostimulants. USA and Europe are the two regions where biostimulants are defined and regulated. However, in other regions, biostimulants are covered by national laws in different categories (organic fertilizers, biofertilizers, plant growth enhancers or plant enhancers). For example, in India biostimulants' main categories are biofertilizers and organic fertilizers, according to the Fertilizer Control Order (FCO) of 1985 and in Brazil, Lei Ordinária No. 6.894/1980 classifies biostimulants as inoculants or biofertilizers.

\subsection{Biopesticides Regulations}

In the EU, biopesticides are regulated as plant protection products under Regulation (EC) $1107 / 2009$ of the European Parliament and of the Council concerning the placing of plant protection products on the market. Thus, this regulation does not recognize biopesticides as a regulatory category. However, reference is made to microorganisms, pheromones and biological products as far as plant protection product is concerned. It is well known that fewer biopesticides are registered in EU than in the United States, India or Brazil, due to the lengthy and complex registration processes involved [44].

In the USA, the term biopesticide is regulated by the following federal agencies: (i) the Environmental Protection Agency (EPA); (ii) the United States Department of Agriculture, the Animal and Plant Health Inspection Service (USDAAPHIS); (iii) the Food and Drug Administration (FDA). In India, the legislation for synthetic pesticides is the same as for biopesticides and is governed under the Insecticides Act (1968). The Central Insecticides Board (CIB) and the Registration Committee (RC) work under this Act as powerful bodies to regulate biopesticides [46]. In Brazil, the Decree 6.913 of 23 July 2009 referred for the first time to the term biopesticide as a phytosanitary product. The registration of biopesticides in this country is regulated through (i) the Ministry of Agriculture; (ii) the Brazilian Institute of Environment and Renewable Natural Resources (IBAMA); (iii) the National Health Surveillance Agency (ANVISA) [47].

\section{Yeasts as Biostimulant and Biofertilizer Agents}

Yeasts are mainly known worldwide for their application in the food industry, but their implementation in different markets has increased in recent years. Nowadays, yeasts are one of the model organisms for biomedical research $[48,49]$ and they have had a great 
impact on the biofuel production industry [50,51]. Similarly, the agricultural sector has also benefited from their use, where research has grown recently [52].

Plant growth-promoting microorganisms (PGPMs) have several beneficial effects on plants due to both direct and indirect mechanisms. Compared to the use of bacteria and mycorrhizal fungi, the use of yeasts as PGPMs has not been extensively investigated. The largest yeast populations are generally found in the rhizosphere rather than in the soil [53]. In fact, a growing number of studies indicate that plant root growth may be favored by yeasts in the rhizosphere $[43,54,55]$, although a wide diversity of soil yeasts has also been investigated for their potential as biofertilizers [32,56,57]. Alternatively, endophytic yeasts, which colonize the interior of the plant, can stimulate crop growth [58-60] as well as there are studies reporting epiphytic yeasts as potential plant growth promoters [60,61]. Their successful results highlight the importance of maintaining the biodiversity of the existing microbiota population in the soil and within plants, which is often diminished by the uncontrolled use of fertilizers. In addition, it should be noted that yeast suspensions in their foliar application could also play an essential role in plants $[62,63]$.

Low availability of some essential nutrients in soluble form can stunt plant growth. Direct mechanisms, including molecular nitrogen $\left(\mathrm{N}_{2}\right)$ fixation, phosphorus $(\mathrm{P})$ and potassium $(\mathrm{K})$ solubilization, solve this problem [64]. Other direct mechanisms are the production of organic acids and plant growth hormones such as auxins, cytokinins or gibberellins. Most attention is given to indole-3-acetic acid (IAA), which is the most common plant auxin responsible for regulating various physiological and growth aspects of plants [65]. As for indirect mechanisms, microbes enhance plant growth through components that induce resistance to environmental stress, leading to the production of antifungal compounds [66].

Some of the mechanisms described and discussed below have not been fully tested by molecular analysis yet, but they have been proposed based on similarities with other biological systems. However, the increasing number of annotated yeast genomes as well as the availability of different transformation techniques should make it possible to better understand different mechanisms and thus will unequivocally highlight the capability of yeasts as PGPMs in the near future.

\subsection{Direct Plant Growth Mechanisms}

\subsubsection{Nutrient Supply}

It is known that one of the main causes of limited yield of most of lower quality crops worldwide is due to the inadequate use of nitrogen [67]. Despite the abundance of nitrogen present in the atmosphere, it is not available in a form suitable for being used by plants, which can only assimilate nitrite, nitrate or ammonia [66]. When using conventional nitrogen fertilization in agriculture, it is often lost during rainfall or by mineral leaching of these fertilizers. On the other hand, biological nitrogen fixation provides ammonium through the action of microorganisms, which in turn is transferred to the plant [66]. While bacteria are the main $\mathrm{N}_{2}$-fixing microorganisms, few is still known about this potential capability of yeasts. Despite this, it has been demonstrated that a strain of Candida tropicalis isolated from soil shows an interesting and great ability to fix nitrogen [68]. On the other hand, studies of ammonia-producing yeasts have been reported with the genus Meyerozyma as the major $\mathrm{NH}_{3}$ producer in the same way that Pseudozyma rugulosa, Cryptococcus flavus and Pseudozyma antarctica are [60,69]. In this way, it is important to highlight the enzyme 1-aminocyclopropane-1-carboxlyate (ACC), which is responsible for the cleavage of the ethylene precursor ACC into $\alpha$-ketobutyrate and ammonia. Thus, the use of this enzyme has a double positive effect: the reduction of the amount of ethylene under adverse conditions, since ethylene can become detrimental to the plant in large quantities, and the release of ammonia, which can generate a nitrogen recycling mechanism for plants through the use of its symbiotic partners $[60,70]$. Yeasts such as C. tropicalis and Cryptococcus sp. have been described with ACC deaminase activity [32,71]. Furthermore, some yeasts have been reported as capable of performing the denitrification process [72]. This is an anaerobic respiration process in which nitrate or nitrite is the final electron acceptor, 
producing nitrous oxide (a greenhouse gas) as final product, contributing in turn to reduce eutrophication [73].

Phosphorus $(\mathrm{P})$ is the second most important key plant nutrient after nitrogen [74]. Thus, $\mathrm{P}$ deficiency is also considered as one of the major limiting factors in crop productivity, especially in the tropic and subtropic regions. This is due to it is the least available element to plants in most soils, unlike other macronutrients [75]. However, soil microorganisms have generally been found to be most effective in making $\mathrm{P}$ available to plants from inorganic and organic sources by solubilization and mineralizing complex P compounds [76]. Among the various strategies adopted by microbes, the mediation of organic acids has made the most sense as the main means of inorganic $P$ solubilization [74]. This is reported by the reduction of $\mathrm{pH}$ under in vitro conditions, which is largely due to the production of carboxylic acids by the microorganism [77]. The yeast $C$. tropicalis was able to solubilize $\mathrm{Ca}_{3}\left(\mathrm{PO}_{4}\right)$ in the same way as Rhodotorula sp. and Lachancea thermotolerans providing soluble inorganic $\mathrm{P}$ with the consequent $\mathrm{pH}$ reduction $[68,69,77]$. Moreover, El-Latif and Mohamed (2011) demonstrated the ability of the some soil strains belonging to Yarrowia lipolytica and Saccharomyces cerevisiae to solubilize inorganic phosphate compounds by producing citric acid [78].

Potassium $(\mathrm{K})$ is the third essential macronutrient for plants. It plays a fundamental role in several processes, including plant growth. The high amounts of K present in soils correspond to insoluble forms of silicate minerals, so K solubilization by microorganisms is also the main mechanism by which this element can be available to plants [79]. Some soil microorganisms are capable of releasing $\mathrm{K}$ from minerals by excreting organic acids that can enhance dissolution by a proton or ligand-mediated mechanism, thus promoting a reduction in the $\mathrm{pH}$ [80]. Results of a study on potassium solubilization from ultramafic alkaline rock dust by the yeast Torulaspora globosa showed high capacity to solubilize $\mathrm{K}$ minerals, being acid production the main mechanism used by the yeast [54]. In another experiment, Rhodotorula glutinis and Pichia anomala recorded the highest concentration of $\mathrm{K}$ released from mica with consequent significant reduction in $\mathrm{pH}$. In addition, it was shown to promote plant height, root and shoot dry weights [80].

PGPMs inoculation can also increase plant uptake of several other nutrients such as calcium, iron, magnesium, sulfur and zinc. This uptake generally occurs during acidification of the soil rhizosphere through organic acid production. While studies have been found reporting $\mathrm{Ca}$ and $\mathrm{Mg}$ solubilization and S oxidation activity by bacteria [81-83], hardly any have been reported in yeasts. Falih and Wainwright (1995) reported the yeasts Williopsis californica and S. cerevisiae as capable of oxidizing elemental S in vitro to produce thiosulfate, tetrathionate and sulfate [84], but no yeasts with this ability have been reported recently. The same cannot be said for iron and zinc, as there are multiple studies of how yeasts can facilitate the assimilation of these nutrients $[43,68,69]$. Regarding the importance of $\mathrm{Zn}$ in plant nutrition, it should be noted that its deficiency causes the development of anomalies in plants, such as stunted growth and smaller leaves, thus highlighting the need to control this nutrient [85]. As for Fe uptake, plants can release phyto-siderophores. However, these tend to have a lower affinity for iron compared to microbial siderophores [86]. Therefore, PGPMs can chelate $\mathrm{Fe}^{3+}$ to make it available to plant roots, absorbing it through the degradation of chelating agents and their consequent release of iron, the direct uptake of siderophore-Fe complexes or through a ligand exchange reaction [87].

\subsubsection{Phytohormones}

Yeasts can produce some plant growth-promoting phytohormones. Among these regulators are auxins, which are a group of compounds that contain an indole ring [65]. Indole-3-acetic acid (IAA) is the major plant growth promoter member of the auxin class which is known to stimulate rapid and long-term responses in plants by regulating various physiological and developmental processes [88]. Studies on IAA-producing yeasts, including Rhodosporidium paludigenum, S. cerevisiae, Aureobasidium pullulans, Candida sp., Dothideomycetes sp, Hanseniaspora uvarum, Meyerozyma caribbica, Meyerozyma guilliermondii, 
Torulaspora sp., Barnettozyma californica, Cryptococcus laurentii, Rhodosporidiobolus fluvialis, Candida maltosa and Pichia kudriavzevii among others, have been reported [43,65,68,69,89-92]. While auxin biosynthesis has not yet been fully elucidated, remarkable progress has been made over the last few years in understanding the mechanism of IAA biosynthesis in yeasts. Two main pathways have been proposed: tryptophan(Trp)-dependent and Trpindependent pathways [89]. As for the Trp-dependent pathway, the possible routes to be used are indole-3-pyruvic acid (IPA), tryptamine (TAM) and indole-3-acetamide (IAM) [89]. It has been demonstrated that the IPA pathway is the main route for the biosynthesis of IAA in yeasts supported by studies with $S$. cerevisiae [92], $R$. paludigenum [65] and $R$. fluvialis [89]. The first step is the conversion of Trp to IPA by aminotransferase activity, then IPA is carboxylated to indole-3-acetaldehyde (IAAld) by indole-3-pyruvate decarboxylase (IPDC) activity and the last step is an oxidation of IAAld to IAA. Alternatively, IPA can also be converted directly to IAA by indole-3-pyruvate monooxygenase [89]. Because IAA production is regulated by several factors such as the strain used, its growth phase, the precursor concentration, or medium components, each yeast has a characteristic biosynthesis pathway [93]. Regarding the Trp-independent pathway, it has been shown that $S$. cerevisiae is able to produce IAA under these conditions; however, the intermediate steps and genes involved in this pathway remain undefined [92]. In addition, Fernandez-San Millan et al. (2020) reported that $97 \%$ of the yeasts used in the study showed Trp-independent IAA biosynthesis capacity [69]. Nevertheless, they suggested that the Trp-dependent pathway was more effective since a higher amount of IAA was obtained.

Another group of phytohormones are the cytokinins, organic molecules that promote plant growth through facilitated cell division and growth. Zeatin is one of the most common cytokinins, which has been reported to be synthetized by some yeasts such as Sporobolomyces roseus, Metschnikowia pulcherrima and A. pullulans. As with auxins, zeatin synthesis in culture varies among species and strains, and may depend on culture conditions [94]. Additionally, gibberellins, commonly known as gibberellic acids, are another important plant growth regulator. Among their abilities, they can stimulate seed germination or trigger the juvenile stage to the adult leaf [95]. The literature does not provide many studies of gibberellic acid production by yeasts. However, a study recently resulted in a high production of gibberellic acid by some of the yeasts isolated from soil, highlighting its potential as a plant growth promoter [96].

\subsection{Indirect Plant Growth Mechanisms}

As discussed above, plants are exposed to a continuous combination pathogenic attacks and extreme environmental factors that limit crop yields. In fact, the latter leads to more than $50 \%$ of crop reductions, which could be increased due to climate change [97]. These include extreme levels of light, ultraviolet radiation, temperature, drought, salinity or metal toxicity [98]. To counteract these stresses, plants are equipped with a large array of defense mechanisms. The accumulation of some functional substances, such as polyamines, induces resistance against extreme environmental stresses [99]. Moreover, they are also involved in various processes of plant growth and development. Thus, polyamines (e.g., spermidine, spermine, putrecine), which consists in low molecular weight aliphatic amines, are considered a new type of plant biostimulant [100]. One of the most common plant hormones that mediates the response to stressors is ethylene [101]. However, when ethylene is produced above its threshold level, it is detrimental to the plant [102]. As discussed above, the enzyme ACC deaminase cleaves ACC to form $\alpha$-ketobutyrate and ammonia. Since ethylene is synthesized from ACC, its depletion affects the biosynthesis of the stress hormone ethylene in host plants and stimulates plant growth [102]. Several studies aimed at evaluating the plant-promoting effect of yeasts tested polyamine and ACC deaminase production with promising results. In this sense, polyamine-producing activity and ACC deaminase activity was reported for the yeast $C$. tropicalis [32]. A large number of yeasts, including P. rugulosa, P. antarctica, A. pullulans and Dothideomycetes spp. 
are polyamine-producing yeasts [43,60]. However, few yeasts have been reported to show ACC deaminase activity among which includes Cryptococcus sp. [71].

\section{Yeasts as Biocontrol against Fungal Pathogenic Microorganisms}

Biological control of fungal attack is also important to consider. As mentioned above, plant growth can also be indirectly influenced by the production of antifungal compounds. Many studies have shown that some yeasts could represent an alternative against fungal infections. It is well known that fungi are proficient in colonization and competition for space and nutrients than other groups of microbes that exist on the surface of fruits and vegetables [103]. Furthermore, yeasts do not usually produce toxic secondary metabolites such as antibiotics, allergenic spores or mycotoxins in their inhibitory activity $[37,104]$, so they can be used as an effective biocontrol agent.

\subsection{Competition for Nutrients and Space}

Since yeasts have different antagonistic properties depending on different factors, including the pathogen, the host and the environment, it is essential to better known about their modes of action in order to improve their viability and increase their potential in disease control. Competition for nutrients and space is considered the main mode of action by yeasts applied post-harvest, especially in fruits [105]. In terms of space, yeasts usually have the advantage of rapid and high growth leading to the formation of biofilms covering the entire wound area fruit [106]. In addition, competition of yeasts for nutrients against some pathogens is also successfully demonstrated in different studies, showing a rapidly depleting of nutrients, thus preventing the germination of fungal spores. In this sense, the ascomycete A. pullulans showed a great biocontrol activity against Penicillium expansum through competition for nutrients [107] and against Monilinia laxa, both through competition for nitrogen compounds and for space [108]. Moreover, iron plays an important role in the growth and virulence of pathogens. Its sequestration, either by pulcherrimine produced by M. pulcherrima $[38,109]$ or by siderophores produced by other yeasts such as R. glutinis [110], hinders the germination and growth of pathogenic fungi due to the lack of iron [36].

\subsection{VOCs and Killer Toxins Production}

On the other hand, yeasts can also produce VOCs, which play an important role in pathogen control [111]. They could be considered as ideal antimicrobials since no physical interaction between the biocontrol agent and the food or pathogen is necessary. Antagonistic yeasts of the genus Hanseniaspora [112] and A. pullulans [113] showed inhibition efficacy against $B$. cinerea by producing VOCs. Similarly, killer toxins can also control post-harvest pathogens [35]. Yeasts that produce these toxins are usually resistant to them and to those of the same class, while they are lethal to other yeast strains [114]. Since the cell wall is one of the most common sites of action of toxins, different components can be found acting as receptors of killer toxins, such as $\beta-1,3$-D-glucans, $\beta$-1,6-D-glucans, mannoproteins and chitin [114]. Some known toxins produced by yeasts are: (i) PMKT and PMKT2, produced by Pichia membranifaciens, which bind, respectively, to $\beta-1,6$-D-glucans and mannoproteins of the cell wall of pathogens [115]; (ii) panomycocin, produced by a strain of $P$. anomala, which exerts its activity by hydrolyzing $\beta$-1,3-glucans [116]; (iii) zymocin, produced by Kluyveromyces lactis, which hydrolyzes chitins present in the fungal cell wall acting as antifungal components [117]. It should be noted that only a small fraction of the recognized killer toxins has been so far characterized in detail [105].

\subsection{Parasitism and iNduced Systemic Resistance}

Parasitism is another mechanism of action whereby there is a direct interaction between the antagonist and the pathogen. The secretion of lytic enzymes and the active development of the antagonist on the pathogenic fungus depends directly on the contact and recognition between them, which usually results in the death of these cells. There 
is evidence that Candida famata, Rhodotorula mucilaginosa, Wickerhamomyces anomalus and P. guilliermondii use parasitism for the biocontrol of Colletotrichum gloeosporioides by secreting enzymes such as $\beta-1,3$-glucanase $[118,119]$. In the same way, induced systemic resistance, mediated by beneficial microbes, is particularly important in biocontrol yeasts. Their responses are effective against necrotrophs [120] and are mediated by the activation of latent defense mechanisms, enhancing the activities of defense-related enzymes [121,122]. It has been possible to demonstrate the beneficial effects of induced resistance in the postharvest environment by treatments with the yeasts $R$. paludigenum and W. anomalus. They significantly reduced the incidence of Penicillium fungal disease through the production of different enzymes like $\beta$-1,3-glucanase [123,124]. Therefore, cell wall degrading enzymes are regaining importance through multiple mechanisms of action. Their study has been made possible by the development of high-throughput sequencing technologies that allows to study changes in gene expression in both host and antagonist tissues, providing information about the origin and regulation of these enzymes [37].

\section{Yeasts as Bioinsecticide, Bioherbicide and Biodegrader}

Biological control also includes insect attacks on plants or the production of weeds that hinder plant growth under ambient conditions. The indiscriminate use of pesticides has led during the last years to the accumulation of toxic residues in food, soil, air or water, as well as the growth of resistance in pests. The development of microbial strategies for the elimination of different substances in a sustainable way is being considered in recent years [125]. It was reported for the first time that the yeast $R$. mucilaginosa could degrade the neonicotinoid insecticides acetamiprid (AAP) and thiacloprid (THI) both in crop and soil, thus promoting bioremediation [31]. Another study addresses the esterasemediated biodegradation of the insecticide chlorpyrifos by the yeasts $R$. glutinis and Rhodotorula rubra [126].

In recent years, there have a growing number of studies in which some yeasts' capabilities to cope with insect pests have been proposed. RNA interference (RNAi) has made important advances as a developmental tool for pest management. It is based on production of double-stranded RNA (dsRNA) in plants and its subsequent ingestion by insects. Down-regulation of genes targeted by the ingested dsRNA via RNAi can trigger reduced growth or the pest's death [127]. In this context, a genetically modified yeast has been able to express dsRNA targeting y-tubulin from Drosophila suzukii. Their results showed that this specific biopesticide decreased larval survival and that the sequence-dependent deletion of the target gene via RNAi was the main cause of the decreased fitness observed in D. suzukii [40]. Additionally, a combination of Cydia pomonella granulovirus and yeasts such as M. pulcherrima, Cryptococcus tephrensis or A. pullulans increased larval mortality and improved fruit protection against apple moth larval infestation. Yeasts stimulate larval feeding as the larvae move to ingest the virus [128]. Another promising approach is the use of food-associated microbial VOCs to trap insect pests in crops. D. suzukii seems to respond to olfactory signals produced mainly by H. uvarum in field experiments, which could be translated into an opportunity for the development of an attract-and-kill control technique [129-131]. Similarly, pheromone-based methods for pest management are frequently used. Due to the high cost of pheromone chemical synthesis production, alternatives are needed. In response, recent studies have shown that pheromone components or precursors can be manufactured from engineered yeasts. The fermentation of the engineered yeast Y. lipolytica produced the sex pheromone of the Helicoverpa armigera worm, which was successfully efficient in field experiments [132].

Herbicides are an important component in food safety. However, the lack of feasible sustainable alternatives requires the constant use of synthetic herbicides. In addition, the increasing demand for food production is leading to a growing market for synthetic herbicides, resulting in high environmental pollution. In recent years, the development of microbial strategies for the elimination of the substances in a sustainable way is being considered [125]. There are many glyphosate-based herbicides [133], whose excess can 
be harmful to animals [134]. In this sense, the yeast Solicoccozyma terricola has the ability to degrade glyphosate in soil and is used as a nutrient source [135]. Besides, a strain of the yeast Clavispora lusitaniae was able to degrade pendimethalin, which is a micro-toxic dinitroaniline herbicide [136], and a strain of P. kudriavzevii managed to degrade atrazine, a member of the s-triazine group of herbicides [137]. This bioremediation capacity that yeasts often exhibited can also be considered a highly interesting approach in sustainable agriculture. While it is known that there are no feasible alternatives to synthetic herbicides, the literature reports that there are auxin herbicides, which are classified as auxins if they induce physiological and phenotypic effects similar to those induced by IAA [41,138]. Due to the large number of phytohormone-producing yeasts mentioned above, these could also be used as a great, yet unknown, alternative.

These different techniques proposed by the studies reviewed, in which yeasts play an important role through direct and indirect mechanisms, are quite promising (Table 1). However, a better understanding of the mechanisms of these microbial agents would be necessary in order to improve our knowledge about their possible effects on both the environment and human health.

Table 1. Applications of yeasts as plant growth promoters, biofungicides, bioinsecticides or biodegraders.

\begin{tabular}{|c|c|c|c|}
\hline Mechanism & Attribute & Yeasts & Reference \\
\hline $\mathrm{N}_{2}$ fixation & $\begin{array}{l}\text { Plant growth } \\
\text { promotion }\end{array}$ & C. tropicalis & [68] \\
\hline $\mathrm{NH}_{3}$ production & $\begin{array}{l}\text { Plant growth } \\
\text { promotion }\end{array}$ & $\begin{array}{l}\text { M. guilliermondii, P. rugulosa, C. flavus, } \\
\text { P. antarctica, Meyerozyma sp., M. caribbica }\end{array}$ & {$[43,60,69]$} \\
\hline P solubilization & $\begin{array}{l}\text { Plant growth } \\
\text { promotion }\end{array}$ & $\begin{array}{l}\text { C. tropicalis, L. thermotolerans, Rhodotorula } \\
\text { sp., H. uvarum, Y. lipolytica, S. cerevisiae }\end{array}$ & {$[32,68,69,77,78]$} \\
\hline K solubilization & $\begin{array}{l}\text { Plant growth } \\
\text { promotion }\end{array}$ & T. globosa, R. glutinis, P. anomala & {$[54,80]$} \\
\hline S oxidizing & $\begin{array}{l}\text { Plant growth } \\
\text { promotion }\end{array}$ & W. californica, S. cerevisiae & [84] \\
\hline Zn solubilization & $\begin{array}{l}\text { Plant growth } \\
\text { promotion }\end{array}$ & $\begin{array}{l}\text { C. tropicalis, L. thermotolerans, } \\
\text { Dothideomycetes sp. }\end{array}$ & {$[43,68,69]$} \\
\hline Polyamine production & $\begin{array}{l}\text { Plant growth } \\
\text { promotion }\end{array}$ & $\begin{array}{l}\text { C. tropicalis, P. rugulosa, P. antarctica, } \\
\text { A. pullulans, Dothideomycetes sp. }\end{array}$ & {$[32,43,60]$} \\
\hline ACC deaminase activity & $\begin{array}{l}\text { Plant growth } \\
\text { promotion }\end{array}$ & C. tropicalis, Cryptococcus sp. & {$[32,71]$} \\
\hline IAA production & $\begin{array}{l}\text { Plant growth } \\
\text { promotion }\end{array}$ & $\begin{array}{l}\text { C. tropicalis, M. guilliermondii, S. cerevisiae, } \\
\text { A. pullulans, H. uvarum, M. caribbica, } \\
\text { W. californica, C. laurentii, R. fluvialis, } \\
\text { C. maltosa, P. kudriavzevii, R. paludigenum }\end{array}$ & {$[43,65,68,69,89-92]$} \\
\hline Cytokinin production & $\begin{array}{l}\text { Plant growth } \\
\text { promotion }\end{array}$ & A. pullulans, S. roseus, M. pulcherrima & [94] \\
\hline Pulcherrimine production & Biofungicide & M. pulcherrima & {$[38,109]$} \\
\hline Siderophore production & Biofungicide & $\begin{array}{l}\text { R. glutinis against } B \text {. cinerea and } \\
\text { P. expansum }\end{array}$ & [110] \\
\hline $\begin{array}{l}\text { Competition for nutrients } \\
\text { and space }\end{array}$ & Biofungicide & $\begin{array}{l}\text { A. pullulans against } P \text {. expansum and } \\
\text { M. laxa; Issatchenkia terricola, P. anomala, } \\
\text { M. pulcherrima, S. cerevisiae, } \\
\text { Schizosaccharomyces pombe, H. uvarum and } \\
\text { P. kluyveri against B. cinerea }\end{array}$ & {$[38,107,108,139-143]$} \\
\hline
\end{tabular}


Table 1. Cont.

\begin{tabular}{|c|c|c|c|}
\hline Mechanism & Attribute & Yeasts & Reference \\
\hline Parasitism & Biofungicide & $\begin{array}{c}\text { M. guilliermondii, P. anomala, } C \text {. famata and } \\
\text { R. mucilaginosa against } C \text {. gloeosporioides; } \\
\text { P. anomala, } A \text {. pullulans and } P \text {. kluyveri } \\
\text { against } B \text {. cinerea }\end{array}$ & {$[38,118,119,140,143]$} \\
\hline VOCs production & Biofungicide & $\begin{array}{l}\text { A. pullulans, Hanseniaspora sp., P. anomala, } \\
\text { M. pulcherrima, P. membranifaciens, } \\
\text { M. guilliermondii, H. uvarum, Starmerella } \\
\text { bacillaris, Candida pyralidae and P. kluyveri } \\
\text { against B. cinerea }\end{array}$ & {$[38,112,113,140,143-147]$} \\
\hline Killer activity & Biofungicide & P. membranifaciens, P. anomala, K. lactis & [115-117] \\
\hline $\begin{array}{l}\text { Induced systemic } \\
\text { resistance }\end{array}$ & Biofungicide & $\begin{array}{l}\text { R. paludigenum against } P \text {. digitatum; } \\
\text { P. anomala against } P \text {. expansum }\end{array}$ & {$[123,124]$} \\
\hline Insecticide biodegradation & Biodegrader & $\begin{array}{c}\text { R. glutinis and } R \text {. rubra } \\
\text { degrades chlorpyrifos; } R \text {. mucilaginosa } \\
\text { degrades neonicotinoid insecticide; } \\
\text { S. terricola degrades glyphosate } \\
\text { insecticide }\end{array}$ & {$[31,126,135]$} \\
\hline Herbicide biodegradation & Biodegrader & $\begin{array}{l}\text { C. lusitaniae degrades dinitroaniline } \\
\text { herbicide; } P \text {. kudriavzevii degrades } \\
\text { s-triazine group herbicides }\end{array}$ & {$[136,137]$} \\
\hline Insecticidal activity & Insecticide & $\begin{array}{l}\text { Y. lipolytica, A. pullulans, H. uvarum, } \\
\text { M. pulcherrima, C. tephrensis }\end{array}$ & {$[128,129,131,132]$} \\
\hline
\end{tabular}

\section{Application of Yeasts in Commercial Biofertilizers and Biopesticides}

The potential advantages of biofertilizers and biopesticides include: (i) a renewable source of nutrients; (ii) maintenance of soil health and microbiota; (iii) reduction of synthetic fertilizers by 25-30\%; (iv) decomposition of plant residues; (v) safety for the environment; (vi) lack of resistance by pests, thus being an environmentally friendly, non-polluting and cost-effective method. However, there are also some limitations, including: (i) lack of availability of suitable and effective strains; (ii) difficulty in marketing as the product contains live organisms; (iii) limited period of activity; (iv) lack of awareness of farmers and inexperienced personnel; (v) low potency and high cost of production [148].

As it can be guessed from what was discussed above, there has been an increase in interest and opportunities in the development and commercialization of bioalternatives that contribute to food security and environmental concerns. Among the commercialized products, it should be highlighted BioGro 2, a multi-strain biofertilizer for rice, which has resulted in shinier, less disease-prone, cleaner and stronger stalks and higher grain yields. It consists in a strain cocktail of bacteria and the yeast $C$. tropicalis [149]. This yeast strain was initially selected for its ability to solubilize insoluble $\mathrm{PO}_{4}$ in agar medium, but it has also been shown to have a set of properties that promote rice plants' growth [32]. The application of this biofertilizer is effective in reducing the use of conventional $\mathrm{N}$ fertilizers by up to $52 \%$ on farms without decreasing rice yields [150]. On the other hand, there is NutriSmart ${ }^{\circledR}$, a biofertilizer composed of a group of $S$. cerevisiae yeast strains that fix atmospheric nitrogen, break down phosphate rock into soluble phosphate and enhance the amount of exchangeable potassium in the soil, so it is free of toxic components. Due to the unique characteristics of yeasts to decompose complex organic matter, various wastes including animal manure, compost and sludge, are often used as substrates. Once applied to the soil, yeasts decompose the residues and release essential elements such as N, P and $\mathrm{K}$. Thus, crop residues can be used to produce these biofertilizers by entering a sustainable recycling loop. Moreover, it has been demonstrated that it increases soil microbial activity while allowing to reduce the use of synthetic fertilizers by $20-30 \%$ [151]. 
Commercial biofungicides include Zimevit, which combines Bacillus subtilis strain UYBC38 and M. pulcherrima strain M26. It has been tested for the control of grapevine gray mold caused by B. cinerea with considerable success [152]. Other commercial antifungal formulations currently traded using yeasts include: Noli or Shemer ${ }^{\mathrm{TM}}$, based on the yeast M. fructicola strain NRRL Y-27328 and commercialized in the Netherlands. Their target pathogens are phytopathogenic fungi belonging to the genera Botrytis, Penicillium, Rhizopus and Aspergillus [39,153-156]; Nexy, formulated with Candida oleophila strain O and marketed in Belgium. This product is effective against Botrytis and Penicillium [157-159]; Botector and BoniProtect ${ }^{\mathrm{TM}}$, marketed in Austria, is developed with two antagonistic strains of $A$. pullulans. The target pathogens in this case are Penicillium, Botrytis and Monilinia (DSM 14940 and DSM 14941), for what it is commonly used for pre-harvest control [160-163]. More biofungicides have been developed with yeast formulations but are not currently being used: Candifruit TM, supported by the yeast Candida sake CPA-1 and produced in Spain, effective against Penicillium, Botrytis and Rhizopus [164-166]; YieldPlus, based on Cryptococcus albidus and developed in South Africa. Their target pathogens were Botrytis, Penicillium, and Mucor [167,168]; Aspire, formulated with C. oleophila strain I-182 and marketed in the USA. It was effective against Botrytis, Penicillium and Monilinia $[169,170]$.

Biofertilizer and biopesticide commercialization remains low globally but is steadily expanding. So much so that no commercial insecticide or herbicide containing yeasts seems to exist so far. In the developed world, where agricultural chemicals remain relatively inexpensive, the use of PGPMs occupies a smaller, but also growing, group [171]. Recent research has revealed yeasts as a promising microorganism for agriculture and has led to improved techniques that can reduce the impact on biodiversity. In fact, the patent literature testifies the industrial interest yeasts application for the design of tailored biotechnological solutions [172]. For example, recent patents proposed specific Metschnikowia fructicola strains to improve plant performance [173] and to inhibit the growth of unwanted microorganisms [174,175]. However, as discussed above, the European Union (EU) Regulation 2019/1009 does not yet consider yeasts as a possible microorganism to be added to biostimulants, so a more widespread use of these will require appropriate regulatory and legal frameworks that are currently strict and may hinder their proper use. Although they are a promising source that offers an alternative for sustainable agriculture, and they are still underexplored as a natural resource. Moreover, their biotechnological potential has not yet been fully explored and requires extensive research for industrial-scale development as a future perspective [176]. Important phases in this research could include: (i) search and development of competent microbial strains that have better host colonization potential and excellent field success; (ii) development of biofertilizers from multi-strain consortia to achieve effective field functions; (iii) the possibility of adding biological substances to improve product formulation; (iv) field experiments at "farmers' scale" [177]. In addition, the production of VOCs or pheromones by yeasts can be proposed as a research challenge to develop a future bioinsecticide. In any case, yeasts would present plant growth promotion, biocontrol and pesticide remediation properties, contributing to boosting agricultural productivity.

\section{Conclusions}

The considerable growth of the world population in the coming years will increase the demand and need for agricultural strategies, including the use of conventional fertilizers. This expansion, in addition to causing the production and accumulation of residues, will also continue to cause the reduction of organic matter in soils. The modification of their physicochemical properties affects the levels of the microbial population, making it essential to search for new options that allow sustainable agriculture. As an alternative to the use of synthetic fertilizers, this review proposes yeasts as a PGPM capable of increasing agricultural productivity directly and indirectly, as well as contributing to soil bioremediation. The intrinsic characteristics of yeasts make them a promising microorganism in agriculture practices because of their usage facilities. Thus, the exploitation of its potential may be a 
promising technique, although it is necessary to better known the mechanisms of action by which PGPMs achieve the benefits in plants and its behaviors in field experiments. The discovery and development of efficient yeasts inoculant consortia that can act under diverse conditions with various plant species, their subsequent optimization, and industrial bioformulation might be one of the bases for developing future biofertilizers. These will be cost-effective, economical and socially acceptable as they will contribute to environmental friendliness and ensure a secure food supply, thus potentially providing a solution.

Author Contributions: Conceptualization, G.C.-B. and J.M.C.; writing—review and editing, M.H.-F., M.R.-M. and G.C.-B.; visualization, G.C.-B. and M.R.-M.; supervision, G.C.-B. and J.M.C. All authors have read and agreed to the published version of the manuscript.

Funding: This research received no external funding.

Institutional Review Board Statement: Not applicable.

Informed Consent Statement: Not applicable.

Data Availability Statement: Not applicable.

Acknowledgments: Authors thanks to Juan José Armario and Mathew Tyndale-Tozer for their selfless English revision.

Conflicts of Interest: The authors declare no conflict of interest.

\section{References}

1. White, P.J.; Brown, P.H. Plant nutrition for sustainable development and global health. Ann. Bot. 2010, 105, 1073-1080. [CrossRef]

2. Gourley, C.J.P.; Dougherty, W.J.; Weaver, D.M.; Aarons, S.R.; Awty, I.M.; Gibson, D.M.; Hannah, M.C.; Smith, A.P.; Peverill, K.I. Farm-scale nitrogen, phosphorus, potassium and sulfur balances and use efficiencies on Australian dairy farms. Anim. Prod. Sci. 2012, 52, 929. [CrossRef]

3. Ceccon, E. La revolución verde. Tragedia en dos actos. Ciencias Univ. Nac. Autónoma México 2008, 1, 21-29.

4. Abdelhafez, A.A.; Abbas, H.H.; Abd-El-Aal, R.S.; Kandil, N.F.; Li, J.; Mahmoud, W. Environmental and Health Impacts of Successive Mineral Fertilization in Egypt. Clean Soil Air Water 2012, 40, 356-363. [CrossRef]

5. Pimentel, D. Green revolution agriculture and chemical hazards. Sci. Total Environ. 1996, 188, S86-S98. [CrossRef]

6. Stolte, J.; Tesfai, M.; Keizer, J. Soil Threats in Europe: Status, Methods, Drivers and Effects on Ecosystem Services; European Commission DG Joint Research Centre: Brussels, Belgium, 2016; ISBN 9789279540189.

7. FAO. The future of food and agriculture-Alternative pathways to 2050 I Global Perspectives Studies I Food and Agriculture Organization of the United Nations. In Food and Agriculture Organization; FAO: Rome, Italy, 2018; p. 224. ISBN 978-92-5-130158-6.

8. Ju, X.; Zhang, F.; Bao, X.; Römheld, V.; Roelcke, M. Utilization and management of organic wastes in Chinese agriculture: Past, present and perspectives. Sci. China C. Life Sci. 2005, 48, 965-979. [CrossRef]

9. Grantina-Ievina, L.; Rodze, I. Survival of Pathogenic and Antibiotic-Resistant Bacteria in Vermicompost, Sewage Sludge, and Other Types of Composts in Temperate Climate Conditions; Springer: Cham, Germany, 2020; pp. 107-124.

10. Case, S.D.C.; Oelofse, M.; Hou, Y.; Oenema, O.; Jensen, L.S. Farmer perceptions and use of organic waste products as fertilisers-A survey study of potential benefits and barriers. Agric. Syst. 2017, 151, 84-95. [CrossRef]

11. Singh, R.P.; Singh, P.; Araujo, A.S.F.; Hakimi Ibrahim, M.; Sulaiman, O. Management of urban solid waste: Vermicomposting a sustainable option. Resour. Conserv. Recycl. 2011, 55, 719-729. [CrossRef]

12. du Jardin, P. Plant biostimulants: Definition, concept, main categories and regulation. Sci. Hortic. 2015, 196, 3-14. [CrossRef]

13. Alori, E.T.; Babalola, O.O. Microbial inoculants for improving crop quality and human health in Africa. Front. Microbiol. 2018, 9 , 2213. [CrossRef]

14. Pandey, V.; Chandra, K. Agriculturally important microorganisms as biofertilizers: Commercialization and regulatory requirements in Asia. In Agriculturally Important Microorganisms: Commercialization and Regulatory Requirements in Asia; Springer: Singapore, 2016; pp. 133-145. ISBN 9789811025761.

15. Bhardwaj, D.; Ansari, M.W.; Sahoo, R.K.; Tuteja, N. Biofertilizers function as key player in sustainable agriculture by improving soil fertility, plant tolerance and crop productivity. Microb. Cell Fact. 2014, 13, 1-10. [CrossRef]

16. Beneduzi, A.; Peres, D.; Vargas, L.K.; Bodanese-Zanettini, M.H.; Passaglia, L.M.P. Evaluation of genetic diversity and plant growth promoting activities of nitrogen-fixing bacilli isolated from rice fields in South Brazil. Appl. Soil Ecol. 2008, 39, 311-320. [CrossRef]

17. Li, J.H.; Wang, E.T.; Chen, W.F.; Chen, W.X. Genetic diversity and potential for promotion of plant growth detected in nodule endophytic bacteria of soybean grown in Heilongjiang province of China. Soil Biol. Biochem. 2008, 40, 238-246. [CrossRef]

18. Vessey, J.K. Plant growth promoting rhizobacteria as biofertilizers. Plant Soil 2003, 255, 571-586. [CrossRef] 
19. Singh, H.; Reddy, S.M. Improvement of wheat and maize crops by inoculating Aspergillus spp. in alkaline soil fertilized with rock phosphate. Arch. Agron. Soil Sci. 2012, 58, 535-546. [CrossRef]

20. Sharma, S.B.; Sayyed, R.Z.; Trivedi, M.H.; Gobi, T.A. Phosphate solubilizing microbes: Sustainable approach for managing phosphorus deficiency in agricultural soils. Springerplus 2013, 2, 1-14. [CrossRef]

21. Nehl, D.B.; Allen, S.J.; Brown, J.F. Deleterious rhizosphere bacteria: An integrating perspective. Appl. Soil Ecol. 1997, 5, 1-20. [CrossRef]

22. Backer, R.; Rokem, J.S.; Ilangumaran, G.; Lamont, J.; Praslickova, D.; Ricci, E.; Subramanian, S.; Smith, D.L. Plant growthpromoting rhizobacteria: Context, mechanisms of action, and roadmap to commercialization of biostimulants for sustainable agriculture. Front. Plant Sci. 2018, 871, 1473. [CrossRef]

23. Gouda, S.; Kerry, R.G.; Das, G.; Paramithiotis, S.; Shin, H.S.; Patra, J.K. Revitalization of plant growth promoting rhizobacteria for sustainable development in agriculture. Microbiol. Res. 2018, 206, 131-140. [CrossRef]

24. E. Birch, A.N.; Begg, G.S.; Squire, G.R. How agro-ecological research helps to address food security issues under new IPM and pesticide reduction policies for global crop production systems. J. Exp. Bot. 2011, 62, 3251-3261. [CrossRef] [PubMed]

25. von Rumker, R.; Kelso, G.; Horay, F.; Lawrence, K.A. A study of the Efficiency of the Use of Pesticides in Agriculture; Office of Pesticide Programs, Environmental Protection Agency, Ed.; EPA Office of Pesticide Programs, Strategic Studies Unit: Washington, DC, USA, 1975; Volume 1.

26. Kour, D.; Rana, K.L.; Yadav, A.N.; Yadav, N.; Kumar, M.; Kumar, V.; Vyas, P.; Dhaliwal, H.S.; Saxena, A.K. Microbial biofertilizers: Bioresources and eco-friendly technologies for agricultural and environmental sustainability. Biocatal. Agric. Biotechnol. 2020, 23, 101487. [CrossRef]

27. Sporleder, M.; Lacey, L.A. Biopesticides. In Insect Pests of Potato; Elsevier Inc.: Amsterdam, The Netherlands, 2013 ; pp. 463-497. ISBN 9780123868954.

28. Olson, S. An analysis of the biopesticide market now and where it is going. Outlooks Pest. Manag. 2015, 26, 203-206. [CrossRef]

29. Kurtzman, C.P.; Fell, J.W.; Boekhout, T. (Eds.) The Yeasts: A Taxonomic Study, 5th ed.; Elsevier: Amsterdam, The Netherlands, 2011; Volume 1, ISBN 978-0-123-84708-9.

30. Yurkov, A.M. Yeasts of the soil-Obscure but precious. Yeast 2018, 35, 369-378. [CrossRef]

31. Dai, Y.J.; Ji, W.W.; Chen, T.; Zhang, W.J.; Liu, Z.H.; Ge, F.; Sheng, Y. Metabolism of the neonicotinoid insecticides acetamiprid and thiacloprid by the yeast Rhodotorula mucilaginosa strain IM-2. J. Agric. Food Chem. 2010, 58, 2419-2425. [CrossRef] [PubMed]

32. Amprayn, K.O.; Rose, M.T.; Kecskés, M.; Pereg, L.; Nguyen, H.T.; Kennedy, I.R. Plant growth promoting characteristics of soil yeast (Candida tropicalis HY) and its effectiveness for promoting rice growth. Appl. Soil Ecol. 2012, 61, 295-299. [CrossRef]

33. Silambarasan, S.; Logeswari, P.; Cornejo, P.; Kannan, V.R. Evaluation of the production of exopolysaccharide by plant growth promoting yeast Rhodotorula sp. strain CAH2 under abiotic stress conditions. Int. J. Biol. Macromol. 2019, 121, 55-62. [CrossRef]

34. Kumla, J.; Nundaeng, S.; Suwannarach, N.; Lumyong, S. Evaluation of multifarious plant growth promoting trials of yeast isolated from the soil of assam tea (Camellia sinensis var. assamica) plantations in Northern Thailand. Microorganisms 2020, 8, 1168. [CrossRef]

35. Freimoser, F.M.; Rueda-Mejia, M.P.; Tilocca, B.; Migheli, Q. Biocontrol yeasts: Mechanisms and applications. World J. Microbiol. Biotechnol. 2019, 35, 154. [CrossRef]

36. Spadaro, D.; Droby, S. Development of biocontrol products for postharvest diseases of fruit: The importance of elucidating the mechanisms of action of yeast antagonists. Trends Food Sci. Technol. 2016, 47, 39-49. [CrossRef]

37. Liu, J.; Sui, Y.; Wisniewski, M.; Droby, S.; Liu, Y. Review: Utilization of antagonistic yeasts to manage postharvest fungal diseases of fruit. Int. J. Food Microbiol. 2013, 167, 153-160. [CrossRef]

38. Cordero-Bueso, G.; Mangieri, N.; Maghradze, D.; Foschino, R.; Valdetara, F.; Cantoral, J.M.; Vigentini, I. Wild Grape-Associated Yeasts as Promising Biocontrol Agents against Vitis vinifera Fungal Pathogens. Front. Microbiol. 2017, 8, 2025. [CrossRef]

39. Droby, S.; Wisniewski, M.; Macarisin, D.; Wilson, C. Twenty years of postharvest biocontrol research: Is it time for a new paradigm? Postharvest Biol. Technol. 2009, 52, 137-145. [CrossRef]

40. Murphy, K.A.; Tabuloc, C.A.; Cervantes, K.R.; Chiu, J.C. Ingestion of genetically modified yeast symbiont reduces fitness of an insect pest via RNA interference. Sci. Rep. 2016, 6, 1-13. [CrossRef]

41. Epp, J.B.; Alexander, A.L.; Balko, T.W.; Buysse, A.M.; Brewster, W.K.; Bryan, K.; Daeuble, J.F.; Fields, S.C.; Gast, R.E.; Green, R.A.; et al. The discovery of Arylex ${ }^{\mathrm{TM}}$ active and Rinskor ${ }^{\mathrm{TM}}$ active: Two novel auxin herbicides. Bioorganic Med. Chem. 2016, 24, 362-371. [CrossRef] [PubMed]

42. Gava, C.A.T.; de Castro, A.P.C.; Pereira, C.A.; Fernandes-Júnior, P.I. Isolation of fruit colonizer yeasts and screening against mango decay caused by multiple pathogens. Biol. Control. 2018, 117, 137-146. [CrossRef]

43. Fu, S.F.; Sun, P.F.; Lu, H.Y.; Wei, J.Y.; Xiao, H.S.; Fang, W.T.; Cheng, B.Y.; Chou, J.Y. Plant growth-promoting traits of yeasts isolated from the phyllosphere and rhizosphere of Drosera spatulata Lab. Fungal Biol. 2016, 120, 433-448. [CrossRef] [PubMed]

44. Damalas, C.A.; Koutroubas, S.D. Current Status and Recent Developments in Biopesticide Use. Agriculture 2018, 8, 13. [CrossRef]

45. Caradonia, F.; Battaglia, V.; Righi, L.; Pascali, G.; La Torre, A. Plant Biostimulant Regulatory Framework: Prospects in Europe and Current Situation at International Level. J. Plant Growth Regul. 2019, 38, 438-448. [CrossRef]

46. Thakur, N.; Kaur, S.; Tomar, P.; Thakur, S.; Yadav, A.N. Microbial biopesticides: Current status and advancement for sustainable agriculture and environment. In New and Future Developments in Microbial Biotechnology and Bioengineering; Elsevier: Amsterdam, The Netherlands, 2020; pp. 243-282. 
47. Mascarin, G.M.; Lopes, R.B.; Delalibera, Í.; Fernandes, É.K.K.; Luz, C.; Faria, M. Current status and perspectives of fungal entomopathogens used for microbial control of arthropod pests in Brazil. J. Invertebr. Pathol. 2019, 165, 46-53. [CrossRef]

48. Gasser, B.; Prielhofer, R.; Marx, H.; Maurer, M.; Nocon, J.; Steiger, M.; Puxbaum, V.; Sauer, M.; Mattanovich, D. Pichia pastoris: Protein production host and model organism for biomedical research. Future Microbiol. 2013, 8, 191-208. [CrossRef]

49. Kumar, R.; Angov, E.; Kumar, N. Potent malaria transmission-blocking antibody responses elicited by Plasmodium falciparum Pfs25 expressed in Escherichia coli after successful protein refolding. Infect. Immun. 2014, 82, 1453-1459. [CrossRef]

50. Kwak, S.; Jo, J.H.; Yun, E.J.; Jin, Y.S.; Seo, J.H. Production of biofuels and chemicals from xylose using native and engineered yeast strains. Biotechnol. Adv. 2019, 37, 271-283. [CrossRef] [PubMed]

51. Zhou, Y.J.; Buijs, N.A.; Zhu, Z.; Qin, J.; Siewers, V.; Nielsen, J. Production of fatty acid-derived oleochemicals and biofuels by synthetic yeast cell factories. Nat. Commun. 2016, 7, 11709. [CrossRef]

52. Mukherjee, A.; Verma, J.P.; Gaurav, A.K.; Chouhan, G.K.; Patel, J.S.; Hesham, A.E.L. Yeast a potential bio-agent: Future for plant growth and postharvest disease management for sustainable agriculture. Appl. Microbiol. Biotechnol. 2020, 104, 1497-1510. [CrossRef]

53. Botha, A. The importance and ecology of yeasts in soil. Soil Biol. Biochem. 2011, 43, 1-8. [CrossRef]

54. Rosa-Magri, M.M.; Avansini, S.H.; Lopes-Assad, M.L.; Tauk-Tornisielo, S.M.; Ceccato-Antonini, S.R. Release of potassium from rock powder by the yeast Torulaspora globosa. Brazilian Arch. Biol. Technol. 2012, 55, 577-582. [CrossRef]

55. El-Maraghy, S.S.; Tohamy, T.A.; Hussein, K.A. Expression of SidD gene and physiological characterization of the rhizosphere plant growth-promoting yeasts. Heliyon 2020, 6, e04384. [CrossRef] [PubMed]

56. Agamy, R.; Hashem, M.; Alamri, S. Effect of soil amendment with yeasts as bio-fertilizers on the growth and productivity of sugar beet. Afr. J. Agric. Res. 2013, 7, 6613-6623. [CrossRef]

57. Nakayan, P.; Hameed, A.; Singh, S.; Young, L.S.; Hung, M.H.; Young, C.C. Phosphate-solubilizing soil yeast Meyerozyma guilliermondii CC1 improves maize (Zea mays L.) productivity and minimizes requisite chemical fertilization. Plant Soil 2013, 373, 301-315. [CrossRef]

58. Khan, Z.; Guelich, G.; Phan, H.; Redman, R.; Doty, S.; Arencibia, A.D.; Chodak, M.; Perez-Artes, E.; Tsushima, S. Bacterial and Yeast Endophytes from Poplar and Willow Promote Growth in Crop Plants and Grasses. Int. Sch. Res. Not. 2012, $2012,11$. [CrossRef]

59. Knoth, J.L.; Kim, S.-H.; Ettl, G.J.; Doty, S.L. Effects of cross host species inoculation of nitrogen-fixing endophytes on growth and leaf physiology of maize. GCB Bioenergy 2013, 5, 408-418. [CrossRef]

60. Nutaratat, P.; Srisuk, N.; Arunrattiyakorn, P.; Limtong, S. Plant growth-promoting traits of epiphytic and endophytic yeasts isolated from rice and sugar cane leaves in Thailand. Fungal Biol. 2014, 118, 683-694. [CrossRef]

61. Sun, P.-F.; Fang, W.-T.; Shin, L.-Y.; Wei, J.-Y.; Fu, S.-F.; Chou, J.-Y. Indole-3-Acetic Acid-Producing Yeasts in the Phyllosphere of the Carnivorous Plant Drosera indica L. PLoS ONE 2014, 9, e114196. [CrossRef]

62. Ibraheim, S.K.A. Effect of Foliar Spray with Some Biostimulants on Growth, Yield and Seeds Quality of Pea Plants Grown in Sandy Soil. J. Appl. Sci. Res. 2014, 10, 400-407.

63. Złotek, U.; Świeca, M. Elicitation effect of Saccharomyces cerevisiae yeast extract on main health-promoting compounds and antioxidant and anti-inflammatory potential of butter lettuce (Lactuca sativa L.). J. Sci. Food Agric. 2016, 96, 2565-2572. [CrossRef] [PubMed]

64. Naik, K.; Mishra, S.; Srichandan, H.; Singh, P.K.; Sarangi, P.K. Plant growth promoting microbes: Potential link to sustainable agriculture and environment. Biocatal. Agric. Biotechnol. 2019, 21, 101326. [CrossRef]

65. Nutaratat, P.; Srisuk, N.; Arunrattiyakorn, P.; Limtong, S. Indole-3-acetic acid biosynthetic pathways in the basidiomycetous yeast Rhodosporidium paludigenum. Arch. Microbiol. 2016, 198, 429-437. [CrossRef] [PubMed]

66. Pérez-Montaño, F.; Alías-Villegas, C.; Bellogín, R.A.; Del Cerro, P.; Espuny, M.R.; Jiménez-Guerrero, I.; López-Baena, F.J.; Ollero, F.J.; Cubo, T. Plant growth promotion in cereal and leguminous agricultural important plants: From microorganism capacities to crop production. Microbiol. Res. 2014, 169, 325-336. [CrossRef]

67. Leghari, S.J.; Wahocho, N.A.; Laghari, G.M.; HafeezLaghari, A.; MustafaBhabhan, G.; HussainTalpur, K.; Bhutto, T.A.; Wahocho, S.A.; Lashari, A.A. Role of nitrogen for plant growth and development: A review. Adv. Environ. Biol. 2016, 10, $209-219$.

68. Mukherjee, S.; Sen, S.K. Exploration of novel rhizospheric yeast isolate as fertilizing soil inoculant for improvement of maize cultivation. J. Sci. Food Agric. 2015, 95, 1491-1499. [CrossRef]

69. Fernandez-San Millan, A.; Farran, I.; Larraya, L.; Ancin, M.; Arregui, L.M.; Veramendi, J. Plant growth-promoting traits of yeasts isolated from Spanish vineyards: Benefits for seedling development. Microbiol. Res. 2020, 237, 126480. [CrossRef] [PubMed]

70. Nascimento, F.X.; Rossi, M.J.; Soares, C.R.F.S.; McConkey, B.J.; Glick, B.R. New Insights into 1-Aminocyclopropane-1-Carboxylate (ACC) Deaminase Phylogeny, Evolution and Ecological Significance. PLoS ONE 2014, 9, e99168. [CrossRef]

71. Deng, Z.; Wang, W.; Tan, H.; Cao, L. Characterization of heavy metal-resistant endophytic yeast Cryptococcus sp. CBSB78 from rapes (Brassica chinensis) and its potential in promoting the growth of Brassica spp. in metal-contaminated soils. Water Air Soil Pollut. 2012, 223, 5321-5329. [CrossRef]

72. Mothapo, N.; Chen, H.; Cubeta, M.A.; Grossman, J.M.; Fuller, F.; Shi, W. Phylogenetic, taxonomic and functional diversity of fungal denitrifiers and associated $\mathrm{N}_{2} \mathrm{O}$ production efficacy. Soil Biol. Biochem. 2015, 83, 160-175. [CrossRef] 
73. Vero, S.; Garmendia, G.; Martínez-Silveira, A.; Cavello, I.; Wisniewski, M. Yeast Activities Involved in Carbon and Nitrogen Cycles in Antarctica. In The Ecological Role of Micro-Organisms in the Antarctic Environment; Springer: Cham, Germany, 2019; pp. 45-64.

74. Khan, M.S.; Zaidi, A.; Ahmad, E. Mechanism of phosphate solubilization and physiological functions of phosphate-solubilizing microorganisms. In Phosphate Solubilizing Microorganisms: Principles and Application of Microphos Technology; Springer International Publishing: Berlin/Heidelberg, Germany, 2014; pp. 31-62, ISBN 9783319082165.

75. Ramaekers, L.; Remans, R.; Rao, I.M.; Blair, M.W.; Vanderleyden, J. Strategies for improving phosphorus acquisition efficiency of crop plants. F. Crop. Res. 2010, 117, 169-176. [CrossRef]

76. Sharma, S.; Kumar, V.; Tripathi, R.B. Isolation of Phosphate Solubilizing Microorganism (PSMs) From Soil. J. Microbiol. Biotechnol. Res. Sch. Res. Libr. J. Microbiol. Biotech. Res. 2011, 1, 90-95.

77. Mundra, S.; Arora, R.; Stobdan, T. Solubilization of insoluble inorganic phosphates by a novel temperature-, pH-, and salt-tolerant yeast, Rhodotorula sp. PS4, isolated from seabuckthorn rhizosphere, growing in cold desert of Ladakh, India. World J. Microbiol. Biotechnol. 2011, 27, 2387-2396. [CrossRef]

78. El-Latif, A.; Mohamed, H.M. Molecular Genetic Identification of Yeast Strains Isolated from Egyptian Soils for Solubilization of Inorganic Phosphates and Growth Promotion of Corn Plants. J. Microbiol. Biotechnol. 2011, 21, 55-61. [CrossRef]

79. Velázquez, E.; Silva, L.R.; Ramírez-Bahena, M.H.; Peix, A. Diversity of potassium-solubilizing microorganisms and their interactions with plants. In Potassium Solubilizing Microorganisms for Sustainable Agriculture; Springer: New Delhi, India, 2016; pp. 99-110, ISBN 9788132227762.

80. Mohamed, H.M.; El-Homosy, R.F.; Abd-Ellatef, A.-E.H.; Salh, F.M.; Hussein, M.Y. Identification of Yeast Strains Isolated from Agricultural Soils for Releasing Potassium-bearing Minerals. Geomicrobiol. J. 2017, 34, 261-266. [CrossRef]

81. Rojas-Tapias, D.; Moreno-Galván, A.; Pardo-Díaz, S.; Obando, M.; Rivera, D.; Bonilla, R. Effect of inoculation with plant growth-promoting bacteria (PGPB) on amelioration of saline stress in maize (Zea mays). Appl. Soil Ecol. 2012, 61, $264-272$. [CrossRef]

82. Aiysha, D.; Latif, Z. Insights of organic fertilizer micro flora of bovine manure and their useful potentials in sustainable agriculture. PLoS ONE 2019, 14, e0226155. [CrossRef] [PubMed]

83. Yang, Z.H.; Stöven, K.; Haneklaus, S.; Singh, B.R.; Schnug, E. Elemental Sulfur Oxidation by Thiobacillus spp. and Aerobic Heterotrophic Sulfur-Oxidizing Bacteria. Pedosphere 2010, 20, 71-79. [CrossRef]

84. Falih, A.M.; Wainwright, M. Nitrification, S-oxidation and P-solubilization by the soil yeast Williopsis californica and by Saccharomyces cerevisiae. Mycol. Res. 1995, 99, 200-204. [CrossRef]

85. Hafeez, B. Role of Zinc in Plant Nutrition- A Review. Am. J. Exp. Agric. 2013, 3, 374-391. [CrossRef]

86. Ansari, R.A.; Mahmood, I.; Rizvi, R.; Sumbul, A. Safiuddin Siderophores: Augmentation of soil health and crop productivity. In Probiotics in Agroecosystem; Springer: Singapore, 2017; pp. 291-312. ISBN 9789811040597.

87. Rajkumar, M.; Ae, N.; Prasad, M.N.V.; Freitas, H. Potential of siderophore-producing bacteria for improving heavy metal phytoextraction. Trends Biotechnol. 2010, 28, 142-149. [CrossRef]

88. Kasahara, H. Current aspects of auxin biosynthesis in plants. Biosci. Biotechnol. Biochem. 2016, 80, 34-42. [CrossRef]

89. Bunsangiam, S.; Sakpuntoon, V.; Srisuk, N.; Ohashi, T.; Fujiyama, K.; Limtong, S. Biosynthetic Pathway of Indole-3-Acetic Acid in Basidiomycetous Yeast Rhodosporidiobolus fluvialis. Mycobiology 2019, 47, 292-300. [CrossRef]

90. Limtong, S.; Koowadjanakul, N. Yeasts from phylloplane and their capability to produce indole-3-acetic acid. World J. Microbiol. Biotechnol. 2012, 28, 3323-3335. [CrossRef] [PubMed]

91. Prabina, B.J.; Kumutha, K.; Anandham, R.; Durga, P. Isolation and Characterization of Multifunctional Yeast as Plant Probiotics for Better Crop Nutrition in Pulses. Int. J. Curr. Microbiol. Appl. Sci. 2019, 8, 2711-2718. [CrossRef]

92. Rao, R.P.; Hunter, A.; Kashpur, O.; Normanly, J. Aberrant Synthesis of Indole-3-Acetic Acid in Saccharomyces cerevisiae Triggers Morphogenic Transition, a Virulence Trait of Pathogenic Fungi. Genetics 2010, 185, 211-220. [CrossRef]

93. Giri, R.; Sharma, R.K. Fungal pretreatment of lignocellulosic biomass for the production of plant hormone by Pichia fermentans under submerged conditions. Bioresour. Bioprocess. 2020, 7, 1-11. [CrossRef]

94. Streletskii, R.A.; Kachalkin, A.V.; Glushakova, A.M.; Yurkov, A.M.; Demin, V.V. Yeasts producing zeatin. PeerJ 2019, 2019 , e6474. [CrossRef]

95. Gupta, R.; Chakrabarty, S.K. Gibberellic acid in plant. Plant Signal. Behav. 2013, 8, e25504. [CrossRef] [PubMed]

96. Pandi, R.; Velu, G.; Devi, P.; Dananjeyan, B. Isolation and screening of soil yeasts for plant growth promoting traits. Madras Agric. J. 2019. [CrossRef]

97. Ramegowda, V.; Senthil-Kumar, M. The interactive effects of simultaneous biotic and abiotic stresses on plants: Mechanistic understanding from drought and pathogen combination. J. Plant Physiol. 2015, 176, 47-54. [CrossRef]

98. Pereira, A. Plant Abiotic Stress Challenges from the Changing Environment. Front. Plant Sci. 2016, 7, 1123. [CrossRef] [PubMed]

99. Hussain, S.S.; Ali, M.; Ahmad, M.; Siddique, K.H.M. Polyamines: Natural and engineered abiotic and biotic stress tolerance in plants. Biotechnol. Adv. 2011, 29, 300-311. [CrossRef]

100. Chen, D.; Shao, Q.; Yin, L.; Younis, A.; Zheng, B. Polyamine function in plants: Metabolism, regulation on development, and roles in abiotic stress responses. Front. Plant Sci. 2019, 9, 1945. [CrossRef]

101. Xu, J.; Zhang, S. Ethylene Biosynthesis and Regulation in Plants. In Ethylene in Plants; Springer: Dordrecht, The Netherlands, 2015; pp. 1-25. 
102. Singh, R.P.; Shelke, G.M.; Kumar, A.; Jha, P.N. Biochemistry and genetics of ACC deaminase: A weapon to "stress ethylene" produced in plants. Front. Microbiol. 2015, 6, 937. [CrossRef]

103. Chanchaichaovivat, A.; Ruenwongsa, P.; Panijpan, B. Screening and identification of yeast strains from fruits and vegetables: Potential for biological control of postharvest chilli anthracnose (Colletotrichum capsici). Biol. Control. 2007, 42, 326-335. [CrossRef]

104. Grebenisan, I.; Cornea, P.; Mateescu, R.; Cimpeanu, C.; Olteanu, V.; Campenu, G.; Stefan, L.A.; Oancea, F.; Lupu, C. Metschnikowia pulcherrima, a new yeast with potential for biocontrol of postharvest fruit rots. In Proceedings of the Acta Horticulturae, International Society for Horticultural Science, Seoul, Korea, 13 August 2006; Volume 767, pp. 355-360.

105. Muccilli, S.; Restuccia, C. Bioprotective Role of Yeasts. Microorganisms 2015, 3, 588. [CrossRef]

106. Klein, M.N.; Kupper, K.C. Biofilm production by Aureobasidium pullulans improves biocontrol against sour rot in citrus. Food Microbiol. 2018, 69, 1-10. [CrossRef]

107. Bencheqroun, S.K.; Bajji, M.; Massart, S.; Labhilili, M.; El Jaafari, S.; Jijakli, M.H. In vitro and in situ study of postharvest apple blue mold biocontrol by Aureobasidium pullulans: Evidence for the involvement of competition for nutrients. Postharvest Biol. Technol. 2007, 46, 128-135. [CrossRef]

108. Di Francesco, A.; Ugolini, L.; D'Aquino, S.; Pagnotta, E.; Mari, M. Biocontrol of Monilinia laxa by Aureobasidium pullulans strains: Insights on competition for nutrients and space. Int. J. Food Microbiol. 2017, 248, 32-38. [CrossRef]

109. Gore-Lloyd, D.; Sumann, I.; Brachmann, A.O.; Schneeberger, K.; Ortiz-Merino, R.A.; Moreno-Beltrán, M.; Schläfli, M.; Kirner, P.; Santos Kron, A.; Rueda-Mejia, M.P.; et al. Snf2 controls pulcherriminic acid biosynthesis and antifungal activity of the biocontrol yeast Metschnikowia Pulcherrima. Mol. Microbiol. 2019, 112, 317-332. [CrossRef]

110. Ferramola, M.I.S.; Benuzzi, D.; Calvente, V.; Calvo, J.; Sansone, G.; Cerutti, S.; Raba, J. The use of siderophores for improving the control of postharvest diseases in stored fruits and vegetables. In Microbial Pathogens and Strategies for Combating Them: Science, Technology and Education; Formatex Research Center: Badajoz, Spain, 2013; pp. 1385-1394.

111. Mari, M.; Bautista-Baños, S.; Sivakumar, D. Decay control in the postharvest system: Role of microbial and plant volatile organic compounds. Postharvest Biol. Technol. 2016, 122, 70-81. [CrossRef]

112. Ruiz-Moyano, S.; Hernández, A.; Galvan, A.I.; Córdoba, M.G.; Casquete, R.; Serradilla, M.J.; Martín, A. Selection and application of antifungal VOCs-producing yeasts as biocontrol agents of grey mould in fruits. Food Microbiol. 2020, 92, 103556. [CrossRef]

113. Di Francesco, A.; Zajc, J.; Gunde-Cimerman, N.; Aprea, E.; Gasperi, F.; Placì, N.; Caruso, F.; Baraldi, E. Bioactivity of volatile organic compounds by Aureobasidium species against gray mold of tomato and table grape. World J. Microbiol. Biotechnol. 2020, 36, 1-11. [CrossRef] [PubMed]

114. Mannazzu, I.; Domizio, P.; Carboni, G.; Zara, S.; Zara, G.; Comitini, F.; Budroni, M.; Ciani, M. Yeast killer toxins: From ecological significance to application. Crit. Rev. Biotechnol. 2019, 39, 603-617. [CrossRef]

115. Belda, I.; Ruiz, J.; Alonso, A.; Marquina, D.; Santos, A. The biology of pichia membranifaciens killer toxins. Toxins 2017, 9 , 112. [CrossRef] [PubMed]

116. Izgu, D.A.; Kepekci, R.A.; Izgu, F. Inhibition of Penicillium digitatum and Penicillium italicum in vitro and in planta with Panomycocin, a novel exo- $\beta-1,3-$ glucanase isolated from Pichia anomala NCYC 434. Antonie Van Leeuwenhoek Int. J. Gen. Mol. Microbiol. 2011, 99, 85-91. [CrossRef] [PubMed]

117. Tzelepis, G.; Karlsson, M. Killer toxin-like chitinases in filamentous fungi: Structure, regulation and potential roles in fungal biology. Fungal Biol. Rev. 2019, 33, 123-132. [CrossRef]

118. Magallon-Andalon, C.G.; Luna-Solano, G.; Ragazzo-Sanchez, J.; Calderon-Santoyo, M. Parasitism and substrate competitions effect of antagonistic yeasts for biocontrol of Colletotrichum gloeosporioides in papaya (Carica papaya L.) var Maradol. Mex. J. Sci. Res. 2012, 1, 2-9.

119. Lima, J.R.; Gondim, D.M.F.; Oliveira, J.T.A.; Oliveira, F.S.A.; Gonçalves, L.R.B.; Viana, F.M.P. Use of killer yeast in the management of postharvest papaya anthracnose. Postharvest Biol. Technol. 2013, 83, 58-64. [CrossRef]

120. Castoria, R.; Wright, S.A.I. Host Responses to Biological Control Agents. In Post-Harvest Pathology; Springer: Berlin/Heidelberg, Germany, 2009; Volume 2, pp. 171-181.

121. Romanazzi, G.; Sanzani, S.M.; Bi, Y.; Tian, S.; Gutiérrez Martínez, P.; Alkan, N. Induced resistance to control postharvest decay of fruit and vegetables. Postharvest Biol. Technol. 2016, 122, 82-94. [CrossRef]

122. Pieterse, C.M.J.; Zamioudis, C.; Berendsen, R.L.; Weller, D.M.; Van Wees, S.C.M.; Bakker, P.A.H.M. Induced systemic resistance by beneficial microbes. Annu. Rev. Phytopathol. 2014, 52, 347-375. [CrossRef]

123. Lu, L.; Lu, H.; Wu, C.; Fang, W.; Yu, C.; Ye, C.; Shi, Y.; Yu, T.; Zheng, X. Rhodosporidium paludigenum induces resistance and defense-related responses against Penicillium digitatum in citrus fruit. Postharvest Biol. Technol. 2013, 85, 196-202. [CrossRef]

124. Zhang, Q.; Zhao, L.; Li, Z.; Li, C.; Li, B.; Gu, X.; Zhang, X.; Zhang, H. Screening and identification of an antagonistic yeast controlling postharvest blue mold decay of pears and the possible mechanisms involved. Biol. Control 2019, 133, 26-33. [CrossRef]

125. Singh, B.; Singh, K. Microbial degradation of herbicides. Crit. Rev. Microbiol. 2016, 42, 245-261. [CrossRef]

126. Bempelou, E.D.; Vontas, J.G.; Liapis, K.S.; Ziogas, V.N. Biodegradation of chlorpyrifos and 3,5,6-trichloro-2-pyridinol by the epiphytic yeasts Rhodotorula glutinis and Rhodotorula rubra. Ecotoxicology 2018, 27, 1368-1378. [CrossRef]

127. Zhang, J.; Khan, S.A.; Heckel, D.G.; Bock, R. Next-Generation Insect-Resistant Plants: RNAi-Mediated Crop Protection. Trends Biotechnol. 2017, 35, 871-882. [CrossRef] [PubMed]

128. Knight, A.L.; Witzgall, P. Combining Mutualistic Yeast and Pathogenic Virus-A Novel Method for Codling Moth Control. J. Chem. Ecol. 2013, 39, 1019-1026. [CrossRef] 
129. Bueno, E.; Martin, K.R.; Raguso, R.A.; Mcmullen, J.G.; Hesler, S.P.; Loeb, G.M.; Douglas, A.E. Response of Wild Spotted Wing Drosophila (Drosophila suzukii) to Microbial Volatiles. J. Chem. Ecol. 2020, 46, 688-698. [CrossRef] [PubMed]

130. Mori, B.A.; Whitener, A.B.; Leinweber, Y.; Revadi, S.; Beers, E.H.; Witzgall, P.; Becher, P.G. Enhanced yeast feeding following mating facilitates control of the invasive fruit pest Drosophila suzukii. J. Appl. Ecol. 2017, 54, 170-177. [CrossRef]

131. Bianchi, F.; Spitaler, U.; Castellan, I.; Cossu, C.S.; Brigadoi, T.; Duménil, C.; Angeli, S.; Robatscher, P.; Vogel, R.F.; Schmidt, S.; et al. Persistence of a yeast-based (Hanseniaspora uvarum) attract-and-kill formulation against drosophila Suzukii on grape leaves. Insects 2020, 11, 810. [CrossRef] [PubMed]

132. Holkenbrink, C.; Ding, B.J.; Wang, H.L.; Dam, M.I.; Petkevicius, K.; Kildegaard, K.R.; Wenning, L.; Sinkwitz, C.; Lorántfy, B.; Koutsoumpeli, E.; et al. Production of moth sex pheromones for pest control by yeast fermentation. Metab. Eng. 2020, 62, 312-321. [CrossRef]

133. Myers, J.P.; Antoniou, M.N.; Blumberg, B.; Carroll, L.; Colborn, T.; Everett, L.G.; Hansen, M.; Landrigan, P.J.; Lanphear, B.P.; Mesnage, R.; et al. Concerns over use of glyphosate-based herbicides and risks associated with exposures: A consensus statement. Environ. Health A Glob. Access Sci. Source 2016, 15, 19. [CrossRef] [PubMed]

134. Gill, J.P.K.; Sethi, N.; Mohan, A.; Datta, S.; Girdhar, M. Glyphosate toxicity for animals. Environ. Chem. Lett. 2018, 16, 401-426. [CrossRef]

135. Stosiek, N.; Terebieniec, A.; Ząbek, A.; Młynarz, P.; Cieśliński, H.; Klimek-Ochab, M. N-phosphonomethylglycine utilization by the psychrotolerant yeast Solicoccozyma terricola M 3.1.4. Bioorg. Chem. 2019, 93, 102866. [CrossRef]

136. Han, Y.; Tang, Z.; Bao, H.; Wu, D.; Deng, X.; Guo, G.; Ye, B.C.; Dai, B. Degradation of pendimethalin by the yeast YC2 and determination of its two main metabolites. RSC Adv. 2019, 9, 491-497. [CrossRef]

137. Abigail, E.A.; Abdul Salam, J.; Das, N. Atrazine degradation in liquid culture and soil by a novel yeast pichia kudriavzevii strain Atz-EN-01 and its potential application for bioremediation. J. Appl. Pharm. Sci. 2013, 3, 35-43. [CrossRef]

138. Quareshy, M.; Prusinska, J.; Li, J.; Napier, R. A cheminformatics review of auxins as herbicides. J. Exp. Bot. 2018, 69, 265-275. [CrossRef]

139. Vargas, M.; Garrido, F.; Zapata, N.; Tapia, M. Isolation and Selection of Epiphytic Yeat for Biocontrol of Botrytis cinerea Pers. on Table Grapes. Chil. J. Agric. Res. 2012, 72, 332-337. [CrossRef]

140. Parafati, L.; Vitale, A.; Restuccia, C.; Cirvilleri, G. Biocontrol ability and action mechanism of food-isolated yeast strains against Botrytis cinerea causing post-harvest bunch rot of table grape. Food Microbiol. 2015, 47, 85-92. [CrossRef] [PubMed]

141. Nally, M.C.; Pesce, V.M.; Maturano, Y.P.; Muñoz, C.J.; Combina, M.; Toro, M.E.; de Figueroa, L.I.C.; Vazquez, F. Biocontrol of Botrytis cinerea in table grapes by non-pathogenic indigenous Saccharomyces cerevisiae yeasts isolated from viticultural environments in Argentina. Postharvest Biol. Technol. 2012, 64, 40-48. [CrossRef]

142. Qin, X.; Xiao, H.; Xue, C.; Yu, Z.; Yang, R.; Cai, Z.; Si, L. Biocontrol of gray mold in grapes with the yeast Hanseniaspora uvarum alone and in combination with salicylic acid or sodium bicarbonate. Postharvest Biol. Technol. 2015, 100, 160-167. [CrossRef]

143. De Simone, N.; Pace, B.; Grieco, F.; Chimienti, M.; Tyibilika, V.; Santoro, V.; Capozzi, V.; Colelli, G.; Spano, G.; Russo, P. Botrytis cinerea and table grapes: A review of the main physical, chemical, and bio-based control treatments in post-harvest. Foods 2020, 9 , 1138. [CrossRef]

144. Kasfi, K.; Taheri, P.; Jafarpour, B.; Tarighi, S. Identification of epiphytic yeasts and bacteria with potential for biocontrol of grey mold disease on table grapes caused by Botrytis cinerea. Span. J. Agric. Res. 2018, 16. [CrossRef]

145. Lemos, W.J.; Bovo, B.; Nadai, C.; Crosato, G.; Carlot, M.; Favaron, F.; Giacomini, A.; Corich, V. Biocontrol ability and action mechanism of Starmerella bacillaris (synonym Candida zemplinina) isolated from wine musts against gray mold disease agent Botrytis cinerea on grape and their effects on alcoholic fermentation. Front. Microbiol. 2016, 7, 1249. [CrossRef]

146. Mewa-Ngongang, M.; Du Plessis, H.W.; Ntwampe, S.K.O.; Chidi, B.S.; Hutchinson, U.F.; Mekuto, L.; Jolly, N.P. The use of Candida pyralidae and Pichia kluyveri to control spoilage microorganisms of raw fruits used for beverage production. Foods $2019,8,454$. [CrossRef]

147. Mew-Ngongang, M.; Du Plessis, H.; Ntwampe, S.K.O.; Chidi, D.B.S.; Hutchinson, U.; Mekuto, L.; Jolly, N. Fungistatic and Fungicidal Behaviour of Candida pyralidae Y1117, Pichia kluyveri Y1125 and Pichia kluyveri Y1164 on the Biocontrol of Botrytis cinerea. In Proceedings of the 10th International Conference on Advances in Science, Engineering, Technology and Healthcare (ASETH-18), Cape Town, South Africa, 19-20 November 2018; pp. 19-20.

148. Kawalekar, J.S. Role of biofertilizers and biopesticides for sustainable agriculture. Ed. J. Bio 2013, 2, 73-78.

149. Nguyen, T.H.; Phan, T.C.; Choudhury, A.T.M.A.; Rose, M.T.; Deaker, R.J.; Kennedy, I.R. Biogro: A plant growth-promoting biofertilizer validated by 15 years' research from laboratory selection to rice farmer's fields of the mekong delta. In AgroEnvironmental Sustainability; Springer International Publishing: Berlin/Heidelberg, Germany, 2017; Volume 1, pp. 237-254, ISBN 9783319497242.

150. Rose, M.T.; Phuong, T.L.; Nhan, D.K.; Cong, P.T.; Hien, N.T.; Kennedy, I.R. Up to 52\% N fertilizer replaced by biofertilizer in lowland rice via farmer participatory research. Agron. Sustain. Dev. 2014, 34, 857-868. [CrossRef]

151. Pang, S.F.; Lui, A.; Goold, G.; Chu, A.; Wong, W.; Li, S.; Chan, E.; Kwok, I.; Cheung, L. NutriSmart®: A fertiliser capable of re-establishing the sustainability of ecosystems and enhancing the productivity of farmland. In Proceedings of the 11th Australian Agronomy Conference, Geelong, VIC, Australia, 2-6 February 2003.

152. Mondino, P.; Casanova, L.; Calero, G.; Bentancur, O.; Alaniz, S. Zimevit: Un biofungicida que combina la acción de una bacteria y una levadura para el control del moho gris de la vid ocasionado por Botrytis cinerea. Rev. Bras. Agroecol. 2012, 7, 127-134. 
153. Zhimo, V.Y.; Kumar, A.; Biasi, A.; Salim, S.; Feygenberg, O.; Toamy, M.A.; Abdelfattaah, A.; Medina, S.; Freilich, S.; Wisniewski, M.; et al. Compositional shifts in the strawberry fruit microbiome in response to near-harvest application of Metschnikowia fructicola, a yeast biocontrol agent. Postharvest Biol. Technol. 2021, 175, 111469. [CrossRef]

154. Kurtzman, C.P.; Droby, S. Metschnikowia fructicola, a new ascosporic yeast with potential for biocontrol of postharvest fruit rots. Syst. Appl. Microbiol. 2001, 24, 395-399. [CrossRef]

155. Karabulut, O.A.; Tezcan, H.; Daus, A.; Cohen, L.; Wiess, B.; Droby, S. Control of preharvest and postharvest fruit rot in strawberry by Metschnikowia fructicola. Biocontrol Sci. Technol. 2004, 14, 513-521. [CrossRef]

156. Prodorutti, D.; Ferrari, A.; Pellegrini, A.; Pertot, I. Efficacy of Metschnikowia fructicola (Shemer®) against post-harvest soft fruit (berries) rots in northern Italy (Trentino). IOBC/WPRS Bull. 2008, 39, 107-113.

157. Lahlali, R.; Jijakli, M.H. Enhancement of the biocontrol agent Candida oleophila (strain O) survival and control efficiency under extreme conditions of water activity and relative humidity. Biol. Control. 2009, 51, 403-408. [CrossRef]

158. Sebastien, M.; Jijakli, M.H. Pichia anomala and Candida oleophila in Biocontrol of Postharvest Diseases of Fruits: 20 Years of Fundamental and Practical Research. In Post-Harvest Pathology; Springer: Berlin/Heidelberg, Germany, 2014; pp. 111-122. ISBN 19077017.

159. Ballet, N.; Souche, J.L.; Vandekerckove, P. Efficacy of Candida oleophila, strain O, In preventing postharvest diseases of fruits. In Proceedings of the Acta Horticulturae, International Society for Horticultural Science, Florence, Italy, 7 June 2016; Volume 1144, pp. 105-111.

160. Weiss, A.; Weißhaupt, S.; Krawiec, P.; Kunz, S. Use of Aureobasidium pullulans for resistance management in chemical control of Botrytis cinerea in berries. Acta Hortic. 2014, 1017, 237-242. [CrossRef]

161. Weiss, A.; Mögel, G.; Kunz, S. Development of "Boni-Protect"-A yeast preparation for use in the control of postharvest diseases of apples. In Proceedings of the 12th International Conference on Cultivation Technique and Phytopathological Problems in Organic, Weinsberg, Germany, 31 January-2 February 2006; Fördergemeinschaft Ökologischer Obstbau e.V. (FÖKO): Weinsberg, Germany, 2006; pp. 1-5.

162. del Fabbro, R.; Crivelli, L.; Lacertosa, G.; Digeronimo, G.; Calari, A.; Edler, B.; D’Ascenzo, D. Activity of Aureobasidium pullulans (Botector) against grey mold on grape, strawberry and tomato. Atti Giornate Fitopatol. Chianciano terme (Siena) 8-11 marzo 2016, 2 , 231-239.

163. Weißhaupt, S.; Hinze, M.; Weiß, A.; Kunz, S. Application of Boni Protect ${ }^{\circ}$ against postharvest diseases in integrated apple production. IOBC-WPRS Bull. 2012, 84, 143-149.

164. Garrido, C.C.; Usall, J.; Torres, R.; Teixidó, N. Effective control of Botrytis bunch rot in commercial vineyards by large-scale application of Candida sake CPA-1. BioControl 2017, 62, 161-173. [CrossRef]

165. Calvo-Garrido, C.; Elmer, P.A.G.; Viñas, I.; Usall, J.; Bartra, E.; Teixidó, N. Biological control of botrytis bunch rot in organic wine grapes with the yeast antagonist Candida sake CPA-1. Plant Pathol. 2013, 62, 510-519. [CrossRef]

166. Calvo-Garrido, C.; Viñas, I.; Usall, J.; Rodríguez-Romera, M.; Ramos, M.C.; Teixidó, N. Survival of the biological control agent Candida sake CPA-1 on grapes under the influence of abiotic factors. J. Appl. Microbiol. 2014, 117, 800-811. [CrossRef]

167. Mbili, N.C.; Laing, M.D.; Yobo, K.S. Integrated control of Penicillium expansum and Botrytis cinerea of apples using potassium silicate, yeast antagonists and YieldPlus ${ }^{\circledR}$. Acta Hortic. 2020, 1269, 75-79. [CrossRef]

168. Kowalska, J.; Drozdzyński, D.; Remlein-Starosta, D.; Sas-Paszt, L.; Malusá, E. Use of Cryptococcus albidus for controlling grey mould in the production and storage of organically grown strawberries. J. Plant Dis. Prot. 2012, 119, 174-178. [CrossRef]

169. Droby, S.; Cohen, L.; Daus, A.; Weiss, B.; Horev, B.; Chalutz, E.; Katz, H.; Keren-Tzur, M.; Shachnai, A. Commercial testing of aspire: A yeast preparation for the biological control of postharvest decay of citrus. Biol. Control. 1998, 12, 97-101. [CrossRef]

170. Wang, Y.; Luo, Y.; Sui, Y.; Xie, Z.; Liu, Y.; Jiang, M.; Liu, J. Exposure of Candida oleophila to sublethal salt stress induces an antioxidant response and improves biocontrol efficacy. Biol. Control. 2018, 127, 109-115. [CrossRef]

171. Timmusk, S.; Behers, L.; Muthoni, J.; Muraya, A.; Aronsson, A.-C. Perspectives and Challenges of Microbial Application for Crop Improvement. Front. Plant Sci. 2017, 8, 49. [CrossRef]

172. De Simone, N.; Capozzi, V.; Amodio, M.L.; Colelli, G.; Spano, G.; Russo, P. Microbial-based Biocontrol Solutions for Fruits and Vegetables: Recent Insight, Patents, and Innovative Trends. Recent Pat. Food Nutr. Agric. 2021, 12, 3-18. [CrossRef]

173. Bayer CropScience AG. Combinations of Biological Control Agents and Insecticides. U.S. Patent Application EP2269455A1, 2011.

174. Droby, S. A Novel Antagonistic Yeast Useful in Controlling Spolage of Agricultural Produce, Methods of Ude Thereof and Compositions Containing Same. European Patent Application WO2002072777A2, 19 September 2002.

175. Roudil, L.; Russo, P.; Berbegal, C.; Albertin, W.; Spano, G.; Capozzi, V. Non-Saccharomyces Commercial Starter Cultures: Scientific Trends, Recent Patents and Innovation in the Wine Sector. Recent Pat. Food Nutr. Agric. 2019, 11, 27-39. [CrossRef] [PubMed]

176. Raimi, A.; Roopnarain, A.; Adeleke, R. Biofertilizer production in Africa: Current status, factors impeding adoption and strategies for success. Sci. Afr. 2021, 11, e00694. [CrossRef]

177. Barquero, M.; Pastor-Buies, R.; Urbano, B.; González-Andrés, F. Challenges, Regulations and Future Actions in Biofertilizers in the European Agriculture: From the Lab to the Field; Springer: Cham, Germany, 2019; pp. 83-107. 